\title{
PASS THROUGH TRAFFIC TRAINING DAPAT MENINGKATKAN KEMAMPUAN PASSING DALAM PERMAINAN SEPAK BOLA
}

\author{
LALU HULFIAN \\ Pendidikan Olahraga dan kesehatan Undikma \\ Email: laluhulfian@ikipmataram.ac.id
}

\begin{abstract}
ABSTRAK
Berdasarkan hasil observasi, peneliti menemukan bahwa teknik dasar passing adalah teknik dasar yang masih sulit dipahami dan dikuasai oleh siswa SSB Montong Gading. Hal ini berpengaruh terhadap prestasi SSB Family Gunugsari tersebut. Menyikapi permasalahan yang ditemukan, perlu ditemukan solusi berupa pemberian program latihan yang bisa meningkatkan kemampuan passing siswa. Peneliti memberikan solusi berupa metode latihan yang diharapkan dapat meningkatkan kemampuan passing yaitu metode latihan pass through traffic. Metode pass through traffic adalah cara untuk melatih keterampilan passing dengan cara pemain berlatih tipuan menggiring bola dan membebasakan menerima umpan. Dengan metode latihan ini yang memberikan sentuhan lebih banyak passing sambil bergerak dan membebaskan pemain bergerak mencari ruang untuk passing dan menerima passing, diharapkan siswa lebih senang bergerak, lebih termotivasi dengan program latihan yang baru dan lebih meningkatkan kemampuan passing mereka. Tujuan dari penelitian ini adalah untuk mengetahui peningkatan yang ditimbulkan oleh Pass Through Traffict training Terhadap Kemampuan Passing Dalam Permainan Sepak Bola. Penelitian merupakan penelitian eksperimen. Metode yang digunakan adalah one-group pretest-posttest design. Populasi penelitian ini adalah seluruh pemain SSB Montong Gading dengan sampel penelitian sebanyak 30 pemain dengan menggunakan purposive sampling. Teknik pengambilan sampel yaitu random sampling. Instrumen yang digunakan dalam tes kemampuan passing adalah menendang bola ke tembok dari jarak 3 meter selama 30 detik.. Teknik analisis yang digunakan adalah dengan menggunakan analisis uji-t dengan SPSS. Hasil penelitian ini menunjukkan bahwa terdapat pengaruh pass through traffic training terhadap kemampuan passing dalam permainan sepak bola pada SSB Montong Gading Hal ini dibuktikan dengan $t_{\text {hitung }}$ sebesar 3,717>ttabel sebesar 2,045, dan nilai signifikansi 0,000 $<0,05$. Jadi dapat disimpulkan ada pengaruh pass through traffic training terhadap kemampuan passing dalam permainan sepak bola
\end{abstract}

Kata Kunci: Pass Through Traffic Training, Kemampuan Passing

\section{PENDAHULUAN}

Dalam olahraga, terdapat berbagai macam cabang olahraga, salah satunya adalah sepakbola. Sepakbola adalah permainan yang membutuhkan fisik dan keaktifan dalam permainannya. Pernyataan tersebut dapat diartikan bahwa sepakbola merupakan permainan beregu yang membutuhkan kekuatan fisik dan skill sehingga dapat bermain sepakbola dengan aktif. Salah satu teknik dasar yang harus dikuasai oleh pemain sepakbola antara lain adalah menendang bola atau kemampuan passing. Permainan ini hampir selurunya menggunakan keterampilan kaki, kecuali penjaga gawang yang diperbolehkan menggunakan tangan di daerahnya yaitu kotak penalti. Dalam perkembangannya permainan ini dapat dimainkan di luar (out door) atau di dalam (in door) (Sucipto dkk, 2000)

Menurut Soewarno (2001) Teknik dasar dalam menendang bola ada tiga yaitu menendang dengan bagian kaki bagian dalam (in side of the foot), bagian samping luar (out side of the foot), dengan kura-kura kaki (instep). Adapun tujuan menendang bola adalah untuk mengoper bola (passing), menembak ke gawang (shootingat the goal), dan menghalau serangan lawan (sweeping). Dalam penelitian ini akan lebih fokus untuk mengembangkan kemampuan passing.

Passing adalah proses mendorong bola dengan bagian kaki tertentu kepada kawan (Mielke, D 2007). Tujuan utama dari passing adalah mengalirkan bola agar tercipta peluang untuk mencetak gol serta agar pemain lawan tidak mudah merebut penguasaan bola karena bola 
terjauhkan dari lawan dengan passing. Passing dibagi menjadi dua jenis yaitu tendangan jarak dekat (short pass) dan tendangan jarak jauh (long pass). Banyak metode latihan yang bisa digunakan untuk meningkatkan hasil passing diantaranya small side game. Small side game adalah latihan yang menggunakan permainan dengan ukuran lapangan yang lebih kecil sehingga sentuhan passing akan lebih banyak dilakukan oleh siswa (Owen A, Twist C, \& Ford P. 2004). Menurut Putera, G (2004) Small side game bisa dilakukan dengan banyak jenis latihan yang dikombinasikan ketika pelaksanaan latihan, hal ini membuat siswa lebih termotivasi melaksanakan latihan karena entuk latihan yang bervariasi. Salah satu bentuk latihan yang bisa digunakan adalah pass trought traffic training.

Teknik passing sangat penting dikuasai oleh pemain sepak bola karena sangat mempengaruhi jalannya taktik dan strategi dalam bermain. Adapun faktor yang mempengaruhi proses penguasaan teknik sepak bola oleh pemain bola dibagi menjadi dua yaitu faktor internal dan faktor eksternal. Menurut Lutan, R. (2000), faktor internal adalah faktor faktor yang ada pada diri seseorang, sedangkan faktor eksternal adalah faktor yang ada di luar diri seseorang yang dapat dimanipulasi guna mengembangkan potensinya.

Menurut hasil wawancara dengan pelatih pembina di SSB Montong Gading dan hasil observasi langsung di lapangan, peneliti menemukan bahwa teknik dasar passing adalah teknik dasar yang masih sulit dipahami dan dikuasai oleh siswa. Hal ini berpengaruh terhadap prestasi SSB Montong Gading. Menyikapi permasalahan yang ditemukan pada pemain SSB ini, perlu ditemukan solusi berupa pemberian program latihan yang bisa meningkatkan kemampuan passing siswa. Peneliti memberikan solusi berupa metode latihan yang diharapkan dapat meningkatkan kemampuan passing pemain SSB Montong Gading yaitu metode latihan pass through traffic. Metode pass through traffic adalah cara untuk melatih keterampilan passing dengan cara pemain berlatih tipuan menggiring bola dan membebasakan menerima umpan. Dengan latihan ini diharapkan siswa lebih senang bergerak, lebih termotivasi dengan program latihan yang baru dan lebih meningkatkan kemampuan passing mereka. Dengan latar belakang ini, peneliti tertarik melakukan penelitian tentang Pengaruh pass through traffic Training terhadap kemampuan passing dalam permainan sepakbola.

\section{Pengaruh}

Pengaruh adalah daya yang timbul dari sesuatu (orang atau benda) yang ikut membentuk watak, kepercayaan atau perbuatan seseorang. Yang dimaksud dengan pengaruh dalam penelitian ini adalah daya yang timbul dari sesorang yang melakukan perbuatan latihan pass through traffic terhadap kemampuan passing dalam permainan sepakbola.

\section{Pass Through Traffic Training}

Pengertian latihan yang berasal dari kata practice adalah aktivitas untuk meningkatkan keterampilan (kemahiran) berolahraga dengan menggunakan berbagai peralatan sesuai dengan tujuan dan kebutuhan cabang olahraganya. (Sukadiyanto dan Muluk, 2011). Metode pass through traffic adalah cara untuk melatih keterampilan passing dengan cara pemain berlatih tipuan menggiring bola dan membebaskan menerima umpan yang dilakukan dengan program latihan dengan set dan repetisi yang sudah ditentukan, frekuensi 3 kali dalam seminggu selama 2 bulan.

\section{Kemampuan Passing}

Passing dalam permainan sepak bola adalah teknik mengoper bola atau memindahkan bola dari satu pemain ke pemain lain. Kemampuan passing dalam penelitian ini adalah kemampuan sampel dalam menendang bola ke tembok dari jarak 3 meter dalam waktu 30 detik.

\section{METODE PENELITIAN}

Penelitian ini adalah jenis penelitian eksperimen dengan desain penelitian one grup pretest postest design. Jumlah subjek dalam penelitian ini sebanyak 30 siswa SSB Montong 
Gading. Teknik sampling yang digunakan adalah purposive sampling yaitu memilih sampel dari populasi berdasarkan kriteria yang dibuat peneliti (Maksum, A. 2009). Instrumen penelitian yang digunakan adalah Tes sepak/mengoper dan Tahan Bola (Passing dan Stopping) dari jarak 3 meter selama 30 detik (Hulfian, L 2014). Teknik pengumpulan data menggunakan tes perbuatan sebagai metode pokok dalam penelitian ini. Teknik analisis data menggunakan rumus t-test berpasangan karena mencari pengaruh dari subjek yang diberikan perlakuan (Hulfian, L. 2015) dan selain itu juga untuk mencari normalitas data digunakan aplikasi SPPS (Kurniawan 2011).

\section{HASIL DAN PEMBAHASAN}

Prosedur penelitian yang dilaksanakan dalam penelitian ini adalah pemilihan subjek dengan purposive sampling sebanyak 30 subjek, kemudian melaksanakan tes awal (pretest) kemampuan passing dengan menggunakan tes yang sudah ditentukan. Pass through traffic training diberikan sebagai treatment terhadap 30 subjek yang sudah dipilih selama 2 bulan dengan frekuensi 3 kali seminggu. Tes akhir (posttest) dilakukan setelah latihan/treatment selesai dilakukan. Hasil pre test dan post test subjek dapat dilihat di tabel berikut.

Tabel 1. Hasil Pre Test Dan Post Test Kemampuan Passing Subjek

\begin{tabular}{ccc}
\multirow{2}{*}{ No Subjek 30 Orang } & \multicolumn{2}{c}{ Kemampuan Passing } \\
\cline { 2 - 3 } & Pre-test & Post-test \\
\hline Jumlah & $\sum 164$ & $\sum 186$ \\
\hline Mean(M) & 7,810 & 8,857 \\
\hline
\end{tabular}

\section{Uji Normalitas Data}

Oleh karena pengolahan data dalam penilaian ini menggunakan uji statisti, maka perlu dilakukan uji persyaratan analisis. Adapun uji persyaratan yang dimaksud adalah uji normalitas dengan menggunakan uji Kolmogorov Smirnov.

Tabel 2. Hasil Uji Normalitas Kolmogorov Smirnov

\begin{tabular}{rrrr} 
Variabel & $\mathrm{P}$ & $\alpha$ & Ket \\
\hline Kemampuan Passing & 0,731 & 0,05 & Normal \\
\hline
\end{tabular}

Hipotesis yang diajukan dalam penelitian ini perlu diuji dan dibuktikan melalui data empiris yang diperoleh di lapangan melalui tes dan pengukuran terhadap variabel yang diteliti. Karena data penelitian mengikuti sebaran normal, maka untuk menguji hipotesis penelitian ini digunakan analisis statistik parametrik dengan menggunakan teknik analisis uji t.

\section{Uji Hipotesis}

Analisis data dilakukan dengan cara manual dan menggunakan aplikasi SPSS. Hasil perhitungan manual ditemukan $\mathbf{t}=\mathbf{3 , 7 1 7}$. pada taraf signifikan 5\% dengan jumlah sampel 30 orang, $\mathrm{t}$ tabel menunjukkan angka sebesar 2,045. Hal ini berarti bahwa 3,717 > 2,045 Berdasarkan kenyataan di atas yaitu nilai thitung lebih besar dari tabel Maka dengan demikian nilai " $t$ " yang diperoleh dalam penelitian adalah "signifikan". Maka Hipotesis Alternatif(Ha) diterima dan Hipotesis Nihil $\left(\mathrm{H}_{0}\right)$ ditolak.

Perhitungan dengan aplikasi SPPS juga menemukan hasil nilai signifikansi p 0,000< 0,05 sehingga ada pengaruh pass through traffic training terhadap kemampuan passing pada pemain SSB Montong Gading

\section{Pembahasan}

Berdasarkan analisis data hasil penelitian diperoleh peningkatan yang signifikan terhadap sampel yang diteliti. Pemberian perlakuan latihan pass through traffic memberikan pengaruh yang signifikan terhadap peningkatan kemampuan passing pada pemain SSB Montong Gading. Adapun urutan kegiatan yang harus dilakukan sehingga akhirnya dapat ditarik kesimpulan 
adalah: (1) diadakan pre-test dengan tujuan supaya kemampuan passing pemain diketahui, (2) pemberian treatment latihan pass through traffic sebanyak 24 kali pertemuan, (3) kemudian yang terakhir adalah diadakannya post-test yang bertujuan untuk mengetahui ada atau tidaknya peningkatan kemampuan passing terhadap subjek yang diberi perlakuan.

Untuk mengetahui adanya perbedaan atau pengaruh latihan pass through traffic terhadap kemampuan passing pada pemain SSB Montong Gading dapat dibuktikan dengan uji-t. Uji-t akan menampilkan besar nilai thitung dan signifikansinya. Hasil uji-t menunjukkan bahwa ada pengaruh yang signifikan latihan pass through traffic terhadap kemampuan passing pada pemain SSB Montong Gading, hal ini dibuktikan dengan $t_{\text {hitung }}$ sebesar 3,717> $t_{\text {tabel }}$ sebesar 2,045, dan nilai signifikansi 0,000 < 0,05. Kemampuan passing pemain SSB Montong Gading mengalami peningkatan setelah melakukan treatment pass through traffic training dengan ditunjukkan oleh nilai post-test lebih besar dari pada nilai pre-test. Hal ini dibuktikan dengan nilai rata-rata post-test sebesar 8,857, lebih baik dari pada nilai rata-rata pre-test sebesar 7,810. Adanya peningkatan kemampuan passing karena pemberian metode atau model latihan pass through traffic yang dilakukan berulang-ulang, sehingga kemampuan dalam melakukan passing meningkat. Hal ini berarti "Ada Pengaruh Latihan Pass Through Traffic terhadap Kemampuan Passing dalam permainan Sepakbola pada SSB Montong Gading Tahun 2021".

Berdasarkan hasil penelitian juga terlihat bahwa ada ada beberapa pemain yang kemampuan passing meningkat drastis, bahkan ada yang peningkatannya sedikit. Hal ini disebabkan jenis penelitian ini merupakan eksperimen semu, artinya peneliti tidak dapat memantau secara penuh kegiatan pemain di luar jadwal latihan/treatment yang diberikan peneliti. Dimungkinkan bagi pemain yang meningkat drastis kemampuannya karena pemain tersebut juga tetap latihan di luar jadwal latihan/treatment yang diberikan peneliti. Sedangkan bagi pemain yang peningkatan kemampuannya sedikit meningkat dimungkinkan pemain tersebut tidak mengikuti latihan secara serius, sehingga hasilnya kurang maksimal.

Hasil penelitian ini sejalan dengan penelitian yang dilakukan oleh Hamdani, R dkk (2021) yaitu latihan drill passing dapat meningkatkan hasil passing bola sepakbola pada pemain sepakbola Usia 8-10 tahun klub SSb Satria 11 Jatipuro Karanganyar. Iqzan F dan Agus A (2021) juga menenmukan peningkatan keteremapilan passing melalui Latihan Wall Pass pada Pemain Sepakbola Bina Muda Pesisir Selatan. Kemampuan passing dapat ditingkatkan melalui latihan yang rutin dan program yang sudah dibuat sesuai dengan prinsip pelatihan. Prinsip pelatihan yang dimaksud adalah dengan frekuensi 3 kali dalam seminggu selama 2 bulan dengan set dan repetisi yang disesuaikan kemampuan subjek.

\section{KESIMPULAN}

Berdasarkan analisis hasil penelitian, dapat disimpulkan bahwa ada pengaruh yang signifikan pada pass through traffic training terhadap kemampuan passing pada pemain SSB Montong Gading Tahun 2021, dengan nilai $\mathrm{t}_{\text {hitung }}$ sebesar 3,717>t $\mathrm{t}_{\text {tabel }}$ sebesar 2,045, dan nilai signifikansi $0,000<0,05$, dan kenaikan rata-rata sebesar 1,048 Berdasarkan kesimpulan penelitian di atas, ada beberapa saran yang dapat disampaikan yaitu : Bagi peneliti selanjutnya agar menambah variabel pembanding. Bagi peneliti selanjutnya agar sampel harus lebih dikontrol. Bagi peneliti selanjutnya agar memberikan program latihan passing pass through traffic dengan lebih jelas dan terprogram.

\section{DAFTAR PUSTAKA}

Hamdani, R. Dkk. (2021). Pengaruh Latihan Pass Go Dan Drill Passing Terhadap Tingkat Akurasi Passing Dalam Sepakbola Pada Anak Usia 8-10 Tahun Klub SSB Satria 11 Jatipuro Karanganyar Tahun 2021. Jurnal ilmiah spirit, Volume 21 no 2 Hlm. 77 - 82

Hulfian, Lalu. (2014). Kondisi Fisik dan Tes Pengukuran dalam Olahraga. Mataram: Lembaga Penelitian dan Pendidikan (LPP) MANDALA

Hulfian. L (2015). Statistik Penelitian untuk Pendidikan Jasmani \& Olahraga. Selong: CV Garuda Ilmu 
Iqzan, F., Agus A. (2021). Latihan Wall Pass Terhadap Keterampilan Passing Pemain Sepakbola Bina Muda Pesisir Selatan. Jurnal Stamina, Volume 2 no 2 Hlm. 23 - 29

Kurniawan, A. 2011. SPSS: Serba-Serbi Analisis Statistic dengan Cepat dan Mudah. Jasakom. Jakarta.

Lutan. R. (2000). Perkembangan Anak. Jakarta: Rineka Cipta.

Maksum, A. (2009). Metodologi Penelitian dalam Olahraga. FIK Unesa. Surabaya

Mielke, D (2007). Dasar - dasar sepak bola. Eastern Oregon university

Owen A, Twist C, \& Ford P. (2004). Small-sided games: The physiological and technical effect of altering pitch size and player numbers. Insight (Volume 7 tahun 2004). Hlm. 50 53.

Putera, G (2004). Mengelola Organisasi Small-Sided Games.Yogyakarta: Kickoff.

Soewarno. (2001). Sepakbola: Gerakan Dasar dan Teknik Dasar. Yogyakarta: Program Studi Pendidikan Kepelatihan Olahraga Fakultas Ilmu Keolahragaan Universitas Negeri Yogyakarta.

Sucipto dkk. (2000). Sepakbola. Jakarta: Pustaka Setia.

Sukadiyanto. \& Muluk, D (2011). Pengantar Teori dan Metodelogi Melatih Fisik. Bandung: CV. Lubuk Agung. 